\title{
Hapten Design and Antibody Preparation on Immunoassay toward the Insecticide Oxamyl
}

\author{
Shiro MiyaKe, ${ }^{*}$ Kosuke Morimune, ${ }^{\dagger}$ Yuki Yamaguchi, Katsuya OHde, \\ Mitsuyasu KaWATA, ${ }^{\dagger}$ Shunichi TAKEWAKI and Yohjiro YUASA ${ }^{\ddagger}$ \\ Iatron Laboratory, Environmental Immuno-chemical Technology Co., Ltd., 1460-6 Mito-aza Mitodai, \\ Tako-machi, Katori-gun, Chiba 289-2247, Japan \\ ${ }^{+}$Naruto Research Laboratories, Environmental Immuno-chemical Technology Co., Ltd. (Otsuka Chemical), \\ 615 Hanamen, Satoura-cho, Naruto, Tokushima 772-8601, Japan \\ $\ddagger$ Environmental Immuno-chemical Technology Co., Ltd. Sun-Kitsukawa Bldg. 27-14, Hamamatsu-cho, \\ 1-chome, Minato-ku, Tokyo 105-0013, Japan
}

(Received December 28, 1998; Accepted October 13, 1999)

\begin{abstract}
To detect small amount of oxamyl, indirect competitive enzyme-linked immunosorbent assays (indirect C-ELISAs) were established. Four haptens for immunogen and three haptens for coating antigen on indirect C-ELISA were synthesized and their polyclonal (PoAbs) and monoclonal antibodies (MoAbs) were prepared. Hapten $N, N$-dimethyl-2-(5-carboxypentyl)carbamoyloxyimino-2-(methylthio)acetamide was the most effective to raise antibodies toward oxamyl out of haptens for immunogen. MoAbs prepared with this hapten were more highly reactive than PoAbs. In particular, MoAb OXM 6-8 showed the highest reactivity. When $N, N$-dimethyl-2-(4-carboxycyclohexyl)carbamoyloxyimino-2-(methylthio) acetamide was used for coating antigen on indirect C-ELISA with OXM 6-8, the highest sensitivity was observed and the concentration for $50 \%$ inhibition value showed $3.6 \mathrm{ng} / \mathrm{ml}$. Methanol extract of potato showed no effect on the reactivity.
\end{abstract}

Key words: oxamyl, hapten, polyclonal antibody, monoclonal antibody, indirect C-ELISA, immunoassay.

\section{INTRODUCTION}

Oxamyl (1), N,N-dimethyl-2-methylcarbamoyloxyimino-2-(methylthio)acetamide, is an oxime carbamate insecticide, acaricide and nematicide, and uniquely exhibits systemic insecticidal and nematicidal activity besides contact activity because of high solubility of water. ${ }^{1)}$ Oxamyl is used for the control of chewing and sucking insects including soil insects and nematodes in vegetables, potatoes, tobacco and other crops in Japan. However, the formulation product including $1 \%$ of oxamyl as an active ingredient, Vydate ${ }^{\circledR}$, is classified into a poison, because of its high toxicity. Therefore, it is very important to monitor oxamyl residues in crops and environments.

A conventional analytical method for oxamyl is performed by gas chromatography (GC) after it is hydrolyzed to an oxime derivative, methyl $N$-hydroxy- $N^{\prime}$, $N^{\prime}$-dimethyl-1-thiooxamimidate. ${ }^{2,3)}$ This method is sen-

\footnotetext{
* To whom correspondence should be addressed.
}

sitive and precise, but laborious and time-consuming since pre-treatments such as hydrolysis are necessary before measurement. Therefore, economical and simple methods have been required to determine oxamyl residues.

Recently, many laboratories reported that immunoassays were sensitive methods to determine pesticide residues and that they had an advantage that the pretreatment of samples could be drastically reduced. ${ }^{4-7)}$ The performance of immunoassays largely depends on reactivity of antibodies toward target molecules. We synthesized highly effective haptens for immunization and prepared oxamyl specific polyclonal antibodies (PoAbs) and monoclonal antibodies (MoAbs). And, the characteristics of the antibodies were compared on indirect competitive enzyme-linked immunosorbent assays (indirect C-ELISAs).

\section{MATERIALS AND METHODS}

\section{Chemicals and Biochemicals}

Alanycarb, aldoxycarb and metolcarb were kindly 
gifted from Otsuka Chemical Co., Ltd., Naruto, Japan. Aldicarb, butocarboxim, butoxycarboxim, oxamyl and thiofanox were purchased from Riedel-de Haën AG, Hannover, Germany. Oxamyl oxime, one of major metabolites of oxamyl, was also kindly given from Otsuka Chemical Co., Ltd.

Keyhole limpet hemocyanin (KLH) was purchased from Pierce Chemical Co., IL, USA. Bovine serum albumin (BSA) was purchased from Sigma Chemical Co., MO, USA. Anti-mouse IgG antibody conjugated with horse radish peroxidase (HRP) was from ICN Pharmaceuticals, Inc., OH, USA. Microtiter plates with 96-wells were purchased from Corning Costar, MA, USA. All other chemicals and reagents were of analytical grade.

\section{Hapten Syntheses}

The chemical structures of haptens employed in this study were listed in Fig. 1.

Proton nuclear magnetic resonance spectra ( ${ }^{1} \mathrm{H}$ NMR) were recorded on a Bruker Avance DPX 300 NMR spectrometer with deuterochloroform as a solvent.

\subsection{Hapten 2}

Hapten 2 was synthesized through compound 9, 10, 11, 12 and 13 , as described below.

\subsubsection{4-(Benzyloxycarbonylamino)butanoic acid (9)}

Benzyl chloroformate $(70 \mathrm{~g}, 410 \mathrm{mmol})$ in $200 \mathrm{ml}$ of $2 \mathrm{M}$ $\mathrm{NaOH}$ was added to $140 \mathrm{ml}$ of $2 \mathrm{M} \mathrm{NaOH}$ containing 4-aminobutanoic acid $(28 \mathrm{~g}, 270 \mathrm{mmol})$ with vigorously

1<smiles>CN(C)C(=O)C(=O)N(C)C</smiles><smiles>CN(C)C(=O)C([13CH3])=NOC(=O)C(=O)O</smiles>

$$
2 n=3
$$

$3 n=5$

$4 n=7$

$5 n=10$

6

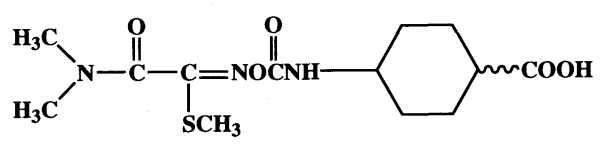

7

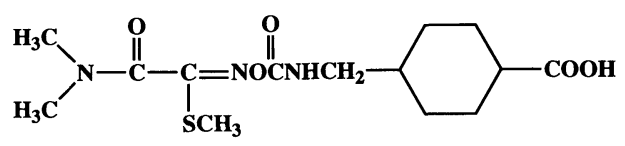

8

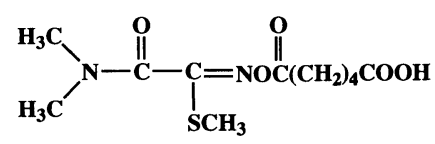

Fig. 1 Chemical structures of oxamyl $\mathbf{1}$, and synthesized hapten $2,3,4,5,6,7$ and 8 . stirring at $0^{\circ} \mathrm{C}$. After stirring for $30 \mathrm{~min}$ at $0^{\circ} \mathrm{C}$, the solution was stirred overnight at room temperature. The solution was washed with $150 \mathrm{ml}$ of cooled diethyl ether and then acidified to $\mathrm{pH} 2$ with conc. $\mathrm{HCl}$ at $0^{\circ} \mathrm{C}$. After 4 times extraction of the solution with $150 \mathrm{ml}$ of dichloromethane, organic layer was combined and dried with anhydrous magnesium sulfate. The dried solution was further filtered and concentrated. The resulting substance was redissolved in ethyl acetate and hexane and then crystallized by standing for $3 \mathrm{hr}$ at $5^{\circ} \mathrm{C}$. As a result, $60 \mathrm{~g}(93 \%)$ of 9 was recovered as a white crystal. ${ }^{1} \mathrm{H}$ NMR $\left(\mathrm{CDCl}_{3}, \mathrm{TMS}\right) \delta \mathrm{ppm}: 1.75-1.91\left(2 \mathrm{H}, \mathrm{m}, \mathrm{CH}_{2}\right.$ $\left.\mathrm{CH}_{2} \mathrm{CH}_{2}\right), 2.40\left(2 \mathrm{H}, \mathrm{t}, J=7.1 \mathrm{~Hz}, \mathrm{CH}_{2} \mathrm{CO}\right), 3.13-3.37$ $\left(2 \overline{\mathrm{H}}, \mathrm{m}, \mathrm{NHCH}_{2}\right), 5.10\left(2 \mathrm{H}, \mathrm{s}, \mathrm{OCH}_{2}\right), 7.34(5 \mathrm{H}, \mathrm{s}, \mathrm{Ar}-\mathrm{H})$. 2.1.2 tert-Butyl 4-(benzyloxycarbonylamino)butanoate (10)

A gentle stream of 2-methylpropene was bubbled into a stirred solution of $9(28 \mathrm{~g}, 118 \mathrm{mmol})$ in $300 \mathrm{ml}$ of dichloromethane at $-15^{\circ} \mathrm{C}$ for $15 \mathrm{~min}$. Nine hundreds twenty $\mu$ l of phosphoric acid $(9.4 \mathrm{mmol})$ and $2.5 \mathrm{ml}$ of boron trifluoride diethyl ether complex $(17.7 \mathrm{mmol})$ was added dropwise, and then 2-methylpropene was bubbled into the solution again for $5 \mathrm{~min}$. The solution was warmed to room temperature and stirred for $24 \mathrm{hr}$. The solution was concentrated under reduced pressure, followed by silica gel chromatography. As a result, $31 \mathrm{~g}$ (90\%) of 10 was recovered as a colorless oil. ${ }^{1} \mathrm{H}$ NMR $\left(\mathrm{CDCl}_{3}, \mathrm{TMS}\right) \delta \mathrm{ppm}: 1.43\left(9 \mathrm{H}, \mathrm{s}, \mathrm{OC}\left(\mathrm{CH}_{3}\right)_{3}\right), 1.69-1.83$ $\left(2 \mathrm{H}, \mathrm{m}, \mathrm{CH}_{2} \mathrm{CH}_{2} \mathrm{CH}_{2}\right), 2.25\left(2 \mathrm{H}, \mathrm{t}, J=7.3 \mathrm{~Hz}, \mathrm{CH}_{2} \mathrm{CO}\right)$, 3.12-3.26 (2H, m, NHCH$\left.{ }_{2}\right), 5.00-5.15\left(3 \mathrm{H}, \mathrm{m}, \overline{\mathrm{CH}}_{2} \mathrm{O} \&\right.$ $\mathrm{CONH}), 7.31(5 \mathrm{H}, \mathrm{s}, \mathrm{Ar}-\mathrm{H})$.

\subsection{3 tert-Butyl 4-aminobutanoate (11)}

Five percent palladium carbon $(1.0 \mathrm{~g})$ was added into a solution of $10(11.7 \mathrm{~g}, 40 \mathrm{mmol})$ in methanol, which was stirred in hydrogen gas until the absorption of hydrogen was completed. The suspension was filtered and concentrated. As a result, $6.1 \mathrm{~g}(100 \%)$ of 11 was recovered as a colorless oil. ${ }^{1} \mathrm{H}$ NMR $\left(\mathrm{CDCl}_{3}, \mathrm{TMS}\right) \delta$ ppm: $1.44\left(9 \mathrm{H}, \mathrm{s}, \mathrm{OC}\left(\mathrm{CH}_{3}\right)_{3}\right), 1.69-1.80\left(2 \mathrm{H}, \mathrm{m}, \mathrm{CH}_{2} \mathrm{CH}_{2}\right.$ $\left.\mathrm{CH}_{2}\right), 2.27\left(2 \mathrm{H}, \mathrm{t}, J=7 . \overline{4} \mathrm{~Hz}, \underline{\mathrm{CH}}_{2} \mathrm{CO}\right), 2.55-2.89(4 \mathrm{H}, \overline{\mathrm{m}}$, $\mathrm{CH}_{2} \mathrm{NH}_{2}$ ).

\subsection{4 tert-Butyl 4-(phenoxycarbonylamino)butanoate} (12)

Solution of $11(6.0 \mathrm{~g}, 3.8 \mathrm{mmol})$ in $50 \mathrm{ml}$ of dichloromethane was added dropwise to stirred solution of phenyl chloroformate $(8.0 \mathrm{~g}, 5.0 \mathrm{mmol})$ in $50 \mathrm{ml}$ of dichloromethane at $0^{\circ} \mathrm{C}$. Then, triethylamine $(5.0 \mathrm{~g}, 5.0$ $\mathrm{mmol}$ ) in dichloromethane was added. The solution was warmed to room temperature and stirred overnight. The mixture was washed with saturated $\mathrm{NaCl}$ solution and dried with anhydrous magnesium sulfate and then concentrated. The resulting substance was redissolved in ethyl acetate and hexane and then crystallized by standing overnight at $5^{\circ} \mathrm{C}$. The precipitate was collected and dried. As a result, $7.4 \mathrm{~g}(70 \%)$ of $\mathbf{1 2}$ was recovered 
as a white crystal. ${ }^{1} \mathrm{H}$ NMR $\left(\mathrm{CDCl}_{3}, \mathrm{TMS}\right) \delta \mathrm{ppm}: 1.46$ $\left(9 \mathrm{H}, \mathrm{s}, \mathrm{OC}\left(\mathrm{CH}_{3}\right)_{3}\right), 1.76-1.97\left(2 \mathrm{H}, \mathrm{m}, \mathrm{CH}_{2} \mathrm{CH}_{2} \mathrm{CH}_{2}\right), 2.30$ $\left(2 \mathrm{H}, \mathrm{t}, J=6.9 \mathrm{~Hz}, \mathrm{CH}_{2} \mathrm{CO}\right), 3.21-3.37\left(2 \mathrm{H}, \overline{\mathrm{m}}, \mathrm{NHCH}_{2}\right)$, 5.11-5.31 (1H, br, $\mathrm{NH}), 7.01-7.41(5 \mathrm{H}, \mathrm{m}, \mathrm{Ar}-\mathrm{H})$.

2.1.5 N,N-dimethyl-2-(tert-butoxybutyl)carbamoyloxyimino-2-(methylthio)acetamide (13)

Solution of 1,8-diazabicyclo[5.4.0] undec-7-ene (3.0 g, $20 \mathrm{mmol}$ ) in $20 \mathrm{ml}$ of dichloromethane was added to stirred solution of methyl $N$-hydroxy- $N^{\prime}, N^{\prime}$-dimethyl-1thiooxamimidate $(3.2 \mathrm{~g}, 20 \mathrm{mmol})$ and $12(5.6 \mathrm{~g}, 20$ $\mathrm{mmol}$ ) in $50 \mathrm{ml}$ of dichloromethane at $0^{\circ} \mathrm{C}$. After stirred at $0^{\circ} \mathrm{C}$, the mixture was stirred at room temperature for 1 $\mathrm{hr}$ and then washed with brine and removed dichloromethane. The resulting substance was purified on silica gel chromatography and $3.6 \mathrm{~g}(52 \%)$ of 13 was recovered as a colorless oil. ${ }^{1} \mathrm{H}$ NMR $\left(\mathrm{CDCl}_{3}\right.$, TMS) $\delta$ ppm: $1.44\left(9 \mathrm{H}, \mathrm{s}, \mathrm{OC}\left(\mathrm{CH}_{3}\right)_{3}\right), 1.80-1.89(2 \mathrm{H}, \mathrm{m}$, $\left.\mathrm{CH}_{2} \mathrm{CH}_{2} \mathrm{CH}_{2}\right), 2.23-2.37\left(2 \mathrm{H}, \mathrm{m}, \mathrm{CH}_{2} \mathrm{CO}\right), 2.31(3 \mathrm{H}, \mathrm{s}$, $\left.\mathrm{SCH}_{3}\right), 3.08\left(3 \mathrm{H}, \mathrm{s}, \mathrm{NCH}_{3}\right), 3.10\left(\overline{3 \mathrm{H}}, \mathrm{s}, \mathrm{NCH}_{3}\right), 3.25-$ $3.37\left(2 \mathrm{H}, \mathrm{m}, \mathrm{NHCH}_{2}\right), 6.05-6.15(1 \mathrm{H}, \mathrm{br}, \mathrm{NH})$.

2.1.6 N, N-dimethyl-2-(3-carboxypropyl)-carbamoyloxyimino-2-(methylthio)acetamide (2)

Ten $\mathrm{ml}$ of trifluoroacetic acid was added to stirred solution of $13(5.6 \mathrm{~g}, 16 \mathrm{mmol})$ in $100 \mathrm{ml}$ of dichloromethane and stirred at room temperature for $24 \mathrm{hr}$. The solution was concentrated under reduced pressure, and the resulting substance was purified on silica gel chromatography. The purified material was crystallized by standing at $-20^{\circ} \mathrm{C}$ and $3.9 \mathrm{~g}(84 \%)$ of 2 was recovered as a colorless oil. ${ }^{1} \mathrm{H}$ NMR $\left(\mathrm{CDCl}_{3}, \mathrm{TMS}\right) \delta \mathrm{ppm}$ : 1.83-1.98 (2H, m, $\left.\mathrm{CH}_{2} \mathrm{CH}_{2} \mathrm{CH}_{2}\right), 2.32\left(3 \mathrm{H}, \mathrm{s}, \mathrm{SCH}_{3}\right), 2.43$ $\left(2 \mathrm{H}, \mathrm{t}, J=7.1 \mathrm{~Hz}, \mathrm{CH}_{2} \mathrm{COOH}\right), 3.08\left(3 \mathrm{H}, \mathrm{s}, \mathrm{NC}_{\overline{\mathrm{H}}}\right), 3.10$ $\left(3 \mathrm{H}, \mathrm{s}, \mathrm{NCH}_{3}\right), 3.29-3.41\left(2 \mathrm{H}, \mathrm{m}, \mathrm{NHCH}_{2}\right), \overline{6.13}-6.22$ $(2 \mathrm{H}, \mathrm{br}, \mathrm{NH}), 7.46-8.48(1 \mathrm{H}, \mathrm{br}, \mathrm{COOH})$.

When 2 was methylated with trimethylsilyldiazomethane, the signal at 7.46-8.48 ppm disappeared and a sharp signal at $3.60 \mathrm{ppm}$ newly appeared in ${ }^{1} \mathrm{H}$ NMR spectrum, which indicated methyl ester.

\subsection{Hapten 3 to hapten 7}

Since these haptens were synthesized in the similar way to that of hapten $\mathbf{2}$, the synthetic routes were not described.

2.2.1 N, N-dimethyl-2-(5-carboxypentyl)carbamoyloxyimino-2-(methylthio) acetamide (3)

${ }^{1} \mathrm{H}$ NMR ( $\mathrm{CDCl}_{3}$, TMS) $\delta \mathrm{ppm}: 1.31-1.72(6 \mathrm{H}, \mathrm{m}$, $\left.\mathrm{CH}_{2} \mathrm{CH}_{2} \mathrm{CH}_{2}\right), 2.29-2.41\left(2 \mathrm{H}, \mathrm{m}, \mathrm{CH}_{2} \mathrm{CO}\right), 2.32(3 \mathrm{H}, \mathrm{s}$, $\left.\mathrm{SCH}_{3}\right), 3.09\left(3 \mathrm{H}, \mathrm{s}, \mathrm{NCH}_{3}\right), 3.10\left(3 \mathrm{H}, \mathrm{s}, \mathrm{NCH}_{3}\right), 5.94-$ $6.08(1 \mathrm{H}, \mathrm{br}, \mathrm{NH}), 7.38-9.05(1 \mathrm{H}, \mathrm{br}, \mathrm{COOH})$.

Methylation of 3 with trimethylsilyldiazomethane showed a signal at $3.67 \mathrm{ppm}$ in ${ }^{1} \mathrm{H}$ NMR spectrum.

2.2.2 N, N-dimethyl-2-(7-carboxyheptyl)carbamoyloxyimino-2-(methylthio)acetamide (4)

${ }^{1} \mathrm{H}$ NMR $\left(\mathrm{CDCl}_{3}\right.$, TMS) $\delta \mathrm{ppm}: 1.20-1.30(6 \mathrm{H}, \mathrm{bs}$, $\left.\left(\mathrm{CH}_{2}\right)_{3}\right), 1.32-1.59\left(4 \mathrm{H}, \mathrm{m}, \mathrm{CH}_{2} \mathrm{CH}_{2}\right), 2.21-2.39(2 \mathrm{H}, \mathrm{m}$, $\left.\mathrm{CH}_{2} \mathrm{CO}\right), 2.32\left(3 \mathrm{H}, \mathrm{s}, \mathrm{SCH}_{3}\right), 3.08\left(3 \mathrm{H}, \mathrm{s}, \mathrm{NC}_{3}\right), 3.10$ $\left(3 \mathrm{H}, \mathrm{s}, \mathrm{NCH}_{3}\right), 3.17-3.30\left(2 \mathrm{H}, \mathrm{m}, \mathrm{NHCH}_{2}\right), 5.92-6.07$ $(1 \mathrm{H}, \mathrm{br}, \mathrm{NH}), 9.24-10.50(1 \mathrm{H}, \mathrm{br}, \mathrm{COOH})$.

Methylation of 4 with trimethylsilyldiazomethane showed a signal at $3.59 \mathrm{ppm}$ in ${ }^{1} \mathrm{H}$ NMR spectrum.

2.2.3 N, N-dimethyl-2-(10-carboxydecyl)carbamoyloxyimino-2-(methylthio)acetamide (5)

${ }^{1} \mathrm{H}$ NMR $\left(\mathrm{CDCl}_{3}\right.$, TMS) $\delta$ ppm: $1.18-1.41(12 \mathrm{H}, \mathrm{bs}$, $\left.\left(\mathrm{CH}_{2}\right)_{6}\right), 1.41-1.70\left(4 \mathrm{H}, \mathrm{m}, \mathrm{CH}_{2} \mathrm{CH}_{2}\right), 2.20-2.38(2 \mathrm{H}, \mathrm{m}$, $\left.\mathrm{CH}_{2} \mathrm{CO}\right), 2.32\left(3 \mathrm{H}, \mathrm{s}, \mathrm{SCH}_{3}\right), 3.08\left(3 \mathrm{H}, \mathrm{s}, \mathrm{NCH}_{3}\right), 3.09$ $\left(3 \overline{\mathrm{H}}, \mathrm{s}, \mathrm{NCH}_{3}\right), 3.17-3.31\left(2 \mathrm{H}, \mathrm{m}, \mathrm{NHCH}_{2}\right), \overline{5.81-6.00}$ $(1 \mathrm{H}, \mathrm{br}, \mathrm{NH}), 8.79-11.85(1 \mathrm{H}, \mathrm{br}, \mathrm{COOH})$.

Methylation of 5 with trimethylsilyldiazomethane showed a signal at $3.67 \mathrm{ppm}$ in ${ }^{1} \mathrm{H}$ NMR spectrum.

2.2.4 N, N-dimethyl-2-(4-carboxycyclohexyl)carbamoyloxyimino-2-(methylthio)acetamide (6)

${ }^{1} \mathrm{H}$ NMR $\left(\mathrm{CDCl}_{3}, \mathrm{TMS}\right) \delta \mathrm{ppm}: 1.51-2.04(8 \mathrm{H}, \mathrm{m}$, $\left.2 \times \mathrm{CH}_{2} \mathrm{CH}_{2}\right), 2.32\left(3 \mathrm{H}, \mathrm{s}, \mathrm{SCH}_{3}\right), 2.51-2.63(1 \mathrm{H}, \mathrm{m}, \mathrm{C}$ $\mathrm{HCOOH}), 3.09\left(3 \mathrm{H}, \mathrm{s}, \mathrm{NCH}_{3}\right), 3.10\left(3 \mathrm{H}, \mathrm{s}, \mathrm{NCH}_{3}\right), 3.66-$ $3.82(1 \mathrm{H}, \mathrm{m}, \mathrm{NHCH}), 5.82-5.98(1 \mathrm{H}, \mathrm{br}, \mathrm{NH}), 8.00-10.20$ $(1 \mathrm{H}, \mathrm{br}, \mathrm{COOH})$.

Methylation of 6 with trimethylsilyldiazomethane showed a signal at $3.69 \mathrm{ppm}$ in ${ }^{1} \mathrm{H}$ NMR spectrum.

2.2.5 N, N-dimethyl-2-[(4-carboxycyclohexyl)methyl] carbamoyl-oxyimino-2-(methylthio)acetamide (7)

${ }^{1} \mathrm{H}$ NMR $\left(\mathrm{CDCl}_{3}, \mathrm{TMS}\right) \delta \mathrm{ppm}: 0.88-1.08(2 \mathrm{H}, \mathrm{m}$, $\left.\mathrm{CH}_{2}\right), 1.31-1.62\left(3 \mathrm{H}, \mathrm{m}, \mathrm{CH}_{2} \& \mathrm{CH}\left(\mathrm{CH}_{2}\right)_{3}\right), 1.73-1.90$ $\left(2 \mathrm{H}, \mathrm{m}, \mathrm{CH}_{2}\right), 1.93-2.08\left(2 \mathrm{H}, \mathrm{m}, \mathrm{CH}_{2}\right), 2.14-2.32(1 \mathrm{H}, \mathrm{m}$, $\mathrm{CHCOOH}), 2.32\left(3 \mathrm{H}, \mathrm{s}, \mathrm{CH}_{3} \mathrm{~S}\right), 2.94-3.20(8 \mathrm{H}, \mathrm{m}, 2 \times$ $\left.\overline{\mathrm{C}}_{3} \mathrm{~N} \& \mathrm{C}_{2} \mathrm{NH}\right), 5.89-6.07$ (1H, br, $\left.\mathrm{NH}\right)$.

Methylation of 7 with trimethylsilyldiazomethane showed a signal at $3.66 \mathrm{ppm}$ in ${ }^{1} \mathrm{H}$ NMR spectrum.

\section{$2.3 \mathrm{~N}, \mathrm{~N}$-dimethyl-2-(4-carboxybutyl)-carbonyloxy- imino-2-(methylthio)acetamide (8)}

Hapten 8 was synthesized by another route. $N$ hydroxy- $N^{\prime}, N^{\prime}$-dimethyl-1-thiooxamimidate $(1.7 \mathrm{~g}, 10.5$ $\mathrm{mmol})$ and pyridine $(0.8 \mathrm{~g}, 10 \mathrm{mmol})$ in $10 \mathrm{ml}$ of dichloromethane, and then a solution of 3,4-dimethoxybenzyl alcohol $(2.0 \mathrm{~g}, 12 \mathrm{mmol})$ and pyridine $(0.8 \mathrm{~g}, 10 \mathrm{mmol})$ in $10 \mathrm{ml}$ of dichloromethane were added to adipoyl chloride $(1.9 \mathrm{~g}, 10.4 \mathrm{mmol})$ in $100 \mathrm{ml}$ of dichloromethane with stirring at $0^{\circ} \mathrm{C}$. After stirred for $2 \mathrm{hr}$, the solution was washed and dried. Then, it was filtered, concentrated and quickly chromatographed on silica gel. The resulting crude product was dissolved in $100 \mathrm{ml}$ of dichloromethane. Ten $\mathrm{ml}$ of trifluoroacetic acid was added and the solution was stirred for $1 \mathrm{hr}$. After concentration, the resulting substance was purified on silica gel chromatography and $1.3 \mathrm{~g}$ (overall yield $43 \%$ ) of 8 was recovered. ${ }^{1} \mathrm{H}$ NMR $\left(\mathrm{CDCl}_{3}\right.$, TMS $) \delta \mathrm{ppm}: 1.64-$ $1.83\left(4 \mathrm{H}, \mathrm{m}, \mathrm{CH}_{2} \mathrm{CH}_{2}\right), 2.33\left(3 \mathrm{H}, \mathrm{s}, \mathrm{SCH}_{3}\right), 2.41(2 \mathrm{H}, \mathrm{t}$, $\left.J=6.8 \mathrm{~Hz}, \quad \overline{\mathrm{CH}}_{2} \mathrm{COON}\right), 2.50(2 \mathrm{H}, \mathrm{t}, J=6.9 \mathrm{~Hz}$, $\left.\mathrm{C}_{2} \mathrm{COOH}\right), 3.05\left(3 \mathrm{H}, \mathrm{s}, \mathrm{NCH}_{3}\right), 3.11\left(3 \mathrm{H}, \mathrm{s}, \mathrm{NC}_{3}\right)$.

Methylation of 8 with trimethylsilyldiazomethane showed a signal at $3.68 \mathrm{ppm}$ in ${ }^{1} \mathrm{H}$ NMR spectrum. 


\section{Preparation of Conjugates of Haptens and Carrier Proteins}

Haptens 2, 3, 4 and 5 were coupled covalently with $\mathrm{KLH}$, respectively. Haptens $2,3,4,5,6,7$ and 8 were coupled with BSA.

One hundred $\mu$ l of each hapten $(5 \mu \mathrm{mol})$ in DMSO was mixed with $5 \mu$ of $N$-hydroxysuccinimide ( $6 \mu \mathrm{mol}$ ) solution in DMSO and immediately followed by the addition of $10 \mu \mathrm{l}$ of water soluble carbodiimide $(6 \mu \mathrm{mol})$ in DMSO. After incubation for $1.5 \mathrm{hr}$ at $25^{\circ} \mathrm{C}$, the reaction mixture was gradually mixed with $1 \mathrm{ml}$ of KLH or BSA $(10 \mathrm{mg})$ solution in $85 \mathrm{~mm}$ borate buffer $(\mathrm{pH} 8.0)$ and incubated for $1.5 \mathrm{hr}$ at $25^{\circ} \mathrm{C}$. Then, the solutions of haptens coupled with the carrier proteins were dialyzed against phosphate buffered saline (PBS) for 2 days at $4^{\circ} \mathrm{C}$.

The dialyzed solutions containing the conjugate of haptens 2, 3, 4 and 5, and KLH (abbreviated as hapten$\mathrm{KLH}$, for example hapten 2-KLH) were used as an immunogen. And the solution containing each hapten 2, 3, 4, 5, 6, 7 and 8 and BSA (abbreviated as haptenBSA, for example hapten 2-BSA) were used as a coating antigen on ELISAs and indirect C-ELISAs.

\section{Preparation of Polyclonal Antibodies}

Each of five 8-week old female Balb/C mice (weight; about $25 \mathrm{~g}$ ) was intra-peritoneally immunized with 100 $\mu \mathrm{g}$ of each hapten-KLH in $50 \mu \mathrm{l}$ of PBS, emulsified with equal volumes of Freund's complete adjuvant, as previously described. ${ }^{8)}$ On 7 days after the boost immunization, the mice were bled through their tail vein, and sera prepared from their blood were used as PoAbs.

\section{Preparation of Monoclonal Antibodies}

The mice mentioned above were finally immunized with the same immunogens on 14 days after the boost immunization. Further 3 days after, their spleen cells were fused with P3-X63-AG8.653 myeloma cells, ${ }^{9)}$ as previously described. ${ }^{10)}$

Then, the hybridomas on the well of microplate with 96-wells were screened and the cells producing specific antibodies were cloned by limiting dilution technique. Their cultured media were used as MoAbs. Subclass of the MoAbs was detected by isotyping kit for mouse MoAbs (Amersham Pharmacia Biotech, UK).

\section{ELISA}

ELISA was carried out to titrate antibodies prepared, based on the procedure as previously described. ${ }^{8)}$ Each well of microtiter plates was coated with $100 \mu$ of each hapten-BSA $(8 \mu \mathrm{g} / \mathrm{ml})$, and this concentration was excess amount of absorption capacity of the wells. A hundred $\mu l$ of PoAbs or MoAbs was added to the wells. After incubation for $1.0 \mathrm{hr}$ at $25^{\circ} \mathrm{C}$, the wells were washed 3 times with PBS and followed by the addition of anti- mouse IgG antibody conjugated with HRP. After the wells were washed 3 times again, the color developments were performed by using 3,3',5,5'-tetramethylbenzidine and the absorbance was measured at $450 \mathrm{~nm}$ by an automated microplate reader (Bio-tek Instruments, VT, USA).

\section{Indirect C-ELISA}

Indirect C-ELISA was carried out based on the procedure, as previously described. ${ }^{8)}$ Exactly, each well of microtiter plates was coated with $100 \mu$ of each haptenBSA $(8 \mu \mathrm{g} / \mathrm{ml})$. Fifty $\mu$ l of oxamyl dissolved in $0 \%$ to $40 \%$ methanol in PBS or samples, which were extracted with methanol from potato and diluted with PBS, were added to the wells. And immediately, $50 \mu \mathrm{l}$ of PoAbs or MoAbs were added to the wells. The antibodies were diluted to final concentrations which gave $50 \%$ of maximum absorbance on the above ELISA. After incubation for $1.0 \mathrm{hr}$ at $25^{\circ} \mathrm{C}$, the wells were washed 3 times and followed by the addition of anti-mouse IgG antibody conjugated with HRP. After the wells were washed 3 times, the color developments and the measurement were performed by the same system as the above ELISA. All of the indirect C-ELISAs were assayed in duplicate and the assays were repeated three times.

When the hapten of hapten-BSA was the same as the hapten for antibody preparation, this indirect C-ELISA was described as homologous C-ELISA. When it was different from the hapten for antibody preparation, this indirect C-ELISA was described as heterologous CELISA.

\section{Preparation of Methanol Extracts from Potato}

A potato (Toyoshiro) was collected from Chiba prefecture, Japan. The potato was cut into small pieces with the skin on and then homogenized with methanol, 3 volume of the potato weight, in a Waring blender (Dynamics Corp., CT, USA). The homogenate was reciprocally shaken for $30 \mathrm{~min}$ and then filtered with celite. After oxamyl fortification, the extract including $75 \%$ methanol equated was used as the extract sample for indirect C-ELISAs.

\section{RESULTS}

\section{Reactivities of Polyclonal Antibodies Raised against Haptens- $K L H$}

$N$-methyl carbamoyl group is a characteristic chemical structure to a number of carbamate pesticides. To synthesize immunizing haptens of oxamyl, methylene groups of the hapten (linker) were elongated from its $N$-methyl group in order to elicit antibodies productions toward oxamyl by preserving its characteristic moiety, as previously described for the other carbamate insecticide carbaryl. ${ }^{11)}$

The reactivity of one PoAb out of five PoAbs immun- 


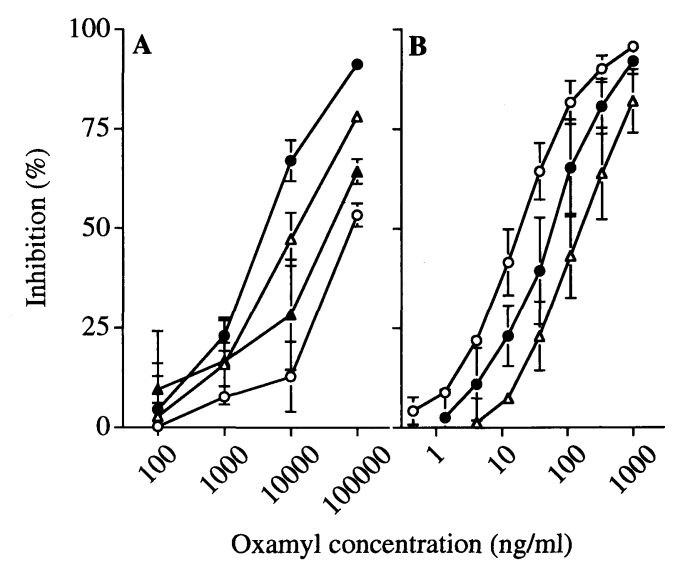

Fig. 2 Reactivities of antibodies with oxamyl on indirect C-ELISAs.

(A) The reactivities of polyclonal antibodies raised against hapten 2-KLH ( $\bigcirc)$, hapten 3-KLH $(\bullet)$, hapten 4-KLH $(\triangle)$ and hapten 5-KLH $(\Delta)$ are shown. (B) The reactivities of monoclonal antibodies, OXM 6-8 ( O), OXM 11-3(•) and OXM 22-26 $(\triangle)$ are shown.

Each value indicates means \pm SD.

ized with each hapten-BSA with oxamyl was compared on homologous C-ELISAs. As shown in Fig. 2-A, PoAbs raised against haptens-KLH with medium length of linkers, hapten 3 and hapten $\mathbf{4}$, showed higher reactivities compared to PoAbs against hapten 2-KLH with the shortest linker and hapten 5-KLH with the longest linker. Hapten $\mathbf{3}$ was in particular shown to be the most effective for the production of the most reactive $\mathrm{PoAb}$ and the concentration for $50 \%$ inhibition $\left(\mathrm{IC}_{50}\right)$ value was $5 \mu \mathrm{g} / \mathrm{ml}$. The results obtained from the other antibodies also showed the similar reactivities.

\section{Reactivities of Monoclonal Antibodies with Oxamyl}

Since $\mathrm{PoAb}$ raised against hapten 3-KLH was the highest reactive antibody with oxamyl among PoAbs examined, the mice immunized with hapten 3-KLH were used to prepare MoAbs.

Hybridomas were screened based on a reaction of their cultured media with oxamyl at the concentration of 1 $\mu \mathrm{g} / \mathrm{ml}$, to select more reacting MoAbs than those of the PoAbs, on indirect C-ELISA. Five hybridoma clones secreted MoAb OXM 6-8, OXM 11-3, OXM 22-26, OXM 31-23 and OXM 64-3 were established. The MoAbs were IgG1 except for OXM 22-26 which was IgG2a.

The reactivities of these MoAbs with oxamyl could be classified to highly reacting group (OXM 6-8 and OXM 64-3), middle reacting group (OXM 11-3 and OXM 3123 ) and low reacting group (OXM 22-26). As shown in Fig. 2-B, the one MoAb out of each group reacted with oxamyl at the concentration from 2 to $100 \mathrm{ng} / \mathrm{ml}$ for OXM 6-8, from 5 to $300 \mathrm{ng} / \mathrm{ml}$ for OXM $11-3$ and from 20 to $1000 \mathrm{ng} / \mathrm{ml}$ for OXM 22-26. The $\mathrm{IC}_{50}$ values were
Table 1 Reactivities of the monoclonal antibodies with oxamyl on heterologous C-ELISAs.

\begin{tabular}{lccc}
\hline & \multicolumn{3}{c}{$\left.\mathrm{IC}_{50}(\mathrm{ng} / \mathrm{ml})^{\mathrm{a}}\right)$} \\
\cline { 2 - 4 } Coating antigen & $\mathrm{OXM}$ & $\mathrm{OXM}$ & $\mathrm{OXM}$ \\
& $6-8$ & $11-3$ & $22-26$ \\
\hline hapten 3-BSA $^{\mathrm{b})}$ & 18 & 48 & $230^{\circ}$ \\
hapten 6-BSA & 3.6 & 12 & 21 \\
hapten 7-BSA & 17 & 43 & 100 \\
hapten 8-BSA & 9.0 & 31 & 67 \\
\hline
\end{tabular}

a) Values for monoclonal antibody OXM 6-8, OXM 11-3 and OXM 22-26 raised against hapten 3-KLH are expressed.

a) Hapten 3-BSA is the coating antigen on homologous C-ELISA.

$18 \mathrm{ng} / \mathrm{ml}$ for OXM 6-8, $48 \mathrm{ng} / \mathrm{ml}$ for OXM $11-3$ and 230 $\mathrm{ng} / \mathrm{ml}$ for OXM 22-26. The other MoAbs in each group also showed the same or slightly less reactivities as the selected one.

Thus, the MoAbs prepared were diversely reactive with oxamyl. Furthermore, these were more reactive than the PoAbs. In particular, the highest reactive OXM 6-8 was 100 folds more reactive than the PoAb raised against hapten 3-KLH. Therefore, the further examinations were made by using the selected MoAbs.

\section{Reactivities of the Monoclonal Antibodies with Oxamyl on Heterologous C-ELISAs}

Heterologous C-ELISAs had been known to be more sensitive than homologous C-ELISAs, as described by M. H. Goodrow. ${ }^{12)}$ Haptens 6 and 7 with a cyclohexyl ring in their alkyl linker and hapten 8 with a tetramethylene group connected with an oxime moiety through ester bond were synthesized for the construction of heterologous C-ELISAs.

As described in Table 1, the reactivities of the MoAbs with oxamyl were enhanced on heterologous C-ELISA with hapten 6-BSA or hapten 8-BSA, respectively. And, hapten 6-BSA enhanced the reactivity in the most effective way, while almost no enhancement was observed on heterologous C-ELISA with hapten 7-BSA. In particular, hapten 6-BSA showed the highest reactivity on heterologous C-ELISA with MoAb OXM 6-8 and the $\mathrm{IC}_{50}$ value was improved to $3.6 \mathrm{ng} / \mathrm{ml}$.

\section{Cross-Reactivity of Monoclonal Antibody OXM 6-8}

Cross-reactivity of OXM 6-8 was examined by using oxamyl and its related compounds, oxamyl oxime and the other carbamate insecticides, on homologous CELISA with hapten 3-BSA and on heterologous CELISA with hapten 6-BSA.

OXM 6-8 did not react with oxamyl oxime and the other carbamate insecticides except for thiofanox on homologous C-ELISA, as described in Table 2. The result suggests that OXM 6-8 recognizes the conforma- 
Table 2 Cross reactivity of monoclonal antibody OXM 6-8 with oxamyl and its related compounds on indirect C-ELISAs.

\begin{tabular}{|c|c|c|c|}
\hline \multirow[b]{2}{*}{ Compound } & \multirow[b]{2}{*}{ Structure } & \multicolumn{2}{|c|}{$\mathrm{IC}_{50}(\mathrm{ng} / \mathrm{ml})$} \\
\hline & & $\begin{array}{c}\text { hapten } \\
\text { 3-BSA }^{\text {a) }}\end{array}$ & $\begin{array}{c}\text { hapten } \\
\text { 6-BSA }\end{array}$ \\
\hline oxamyl & $\begin{array}{c}\mathrm{SCH}_{3} \\
\left(\mathrm{CH}_{3}\right)_{2} \mathrm{~N}-\mathrm{CO}-\mathrm{C}=\mathrm{NOCONHCH}_{3}\end{array}$ & 18 & 3.6 \\
\hline oxamyl oxime & $\begin{array}{ll} & \left(\mathrm{CH}_{3}\right)_{2} \mathrm{~N}-\mathrm{CO}-\stackrel{\mathrm{C}}{\mathrm{C}}=\mathrm{NOH} \\
\mathrm{CH}_{3} \quad \stackrel{\mathrm{CH}_{3}}{ }\end{array}$ & $>10,000$ & $>10,000$ \\
\hline alanycarb & $\underset{\substack{\mathrm{CH}_{3} \mathrm{~S}-\mathrm{C}=\mathrm{NOCON}_{3} \mathrm{~S}-\mathrm{N}-\mathrm{CH}_{2} \\
\mathrm{CH}_{3} \mathrm{CH}_{2} \mathrm{CO}_{2} \mathrm{CH}_{2} \mathrm{CH}_{2}}}{\mathrm{CH}_{3}}$ & $>10,000$ & $>10,000$ \\
\hline aldicarb & 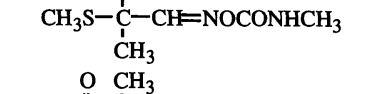 & $>10,000$ & $>10,000$ \\
\hline aldoxycarb & $\begin{array}{c}\mathrm{CH}_{3} \stackrel{\mathrm{H}}{\mathrm{S}}-\stackrel{\grave{\mathrm{C}}}{\mathrm{C}}-\mathrm{CH}=\mathrm{NOCONHCH}_{3} \\
\stackrel{\mathrm{O}}{\mathrm{C}} \mathrm{H}_{3} \mathrm{CH}_{3}\end{array}$ & $>10,000$ & $>10,000$ \\
\hline butocarboxim & $\underset{\mathrm{CH}_{3}}{\mathrm{CH}_{3} \mathrm{~S}-\mathrm{CH}=\mathrm{NOCONHCH}_{3}}$ & $>10,000$ & 3100 \\
\hline butoxycarboxim & $\begin{array}{l}\stackrel{\mathrm{O}}{\mathrm{O}} \underset{\mathrm{M}}{\mathrm{CH}} \mathrm{CH}_{3} \\
\mathrm{CH}_{3}^{\mathrm{S}}-\mathrm{C} \mathrm{CH} \\
\mathrm{O}=\mathrm{CH}_{3}\end{array}$ & $>10,000$ & $>10,000$ \\
\hline metolcarb & $\gamma-O C O N$ & $>10,000$ & $>10,000$ \\
\hline thiofanox & $\mathrm{CH}_{3} \mathrm{~S}-\mathrm{CH}_{2}-\stackrel{1}{\mathrm{C}}=\mathrm{NOCONHCH}_{3}$ & 12 & 5.1 \\
\hline
\end{tabular}

a) Values on homologous C-ELISA with hapten 3-BSA are expressed. b) Values on heterologous C-ELISA with hapten 6-BSA are expressed.

tion of oxamyl and that thiofanox may have a similar conformation to oxamyl.

On the other hand, on heterologous C-ELISA, OXM 6-8 showed a little higher reactivity to oxamyl than thiofanox. OXM 6-8 did not react with the other compounds except for butocarboxim, which reacted weakly. These results suggest that OXM 6-8 on heterologous C-ELISA is a little more specific to oxamyl compared to the homologous C-ELISA.

\section{Effect of Methanol Concentration on the Reactivity of OXM 6-8 with Oxamyl}

Oxamyl residues in crops are generally analyzed by using extracts with organic solvents. Methanol, which was known to be mild solvent on immunoassays, ${ }^{13,14)}$ was also examined on homologous C-ELISA with hapten 3-BSA and heterologous C-ELISA with hapten 6-BSA.

When methanol at final concentration of $0 \%$ to $40 \%$ was added to the reaction mixtures on homologous C-ELISA, the reactivity curve was parallel shifted lower and the sensitivity was decreased depending on methanol concentration. On the other hand, in the case of heterologous C-ELISA, the reactivity curve did not change below $10 \%$ methanol concentration and the sensitivity was kept even at $20 \%$ methanol concentration, as shown in Fig. 3.

Thus, heterologous C-ELISA was more convenient to

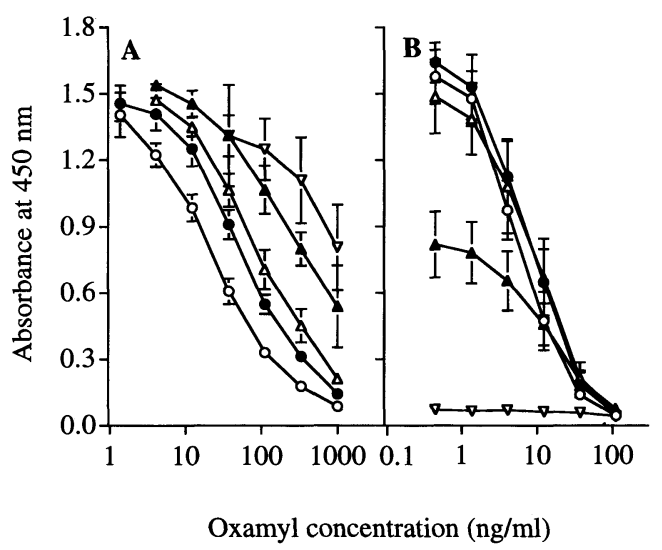

Fig. 3 Effect of methanol concentration on reactivity of monoclonal antibody OXM 6-8 with oxamyl on homologous C-ELISA with hapten 3-BSA (A) and heterologous C-ELISA with hapten 6-BSA (B).

Zero\% $(\bigcirc), 5 \%(\bullet), 10 \%(\triangle), 20 \%(\triangle)$ and $40 \%(\nabla)$ of methanol were contained in reaction mixture. Each value indicates means $\pm \mathrm{SD}$.

determine oxamyl residues than homologous C-ELISA.

\section{Reactivity of OXM 6-8 with Oxamyl in Methanol Extract from potato}

Since oxamyl was widely used to control parasitic nematodes in potato fields, the assay of oxamyl in 


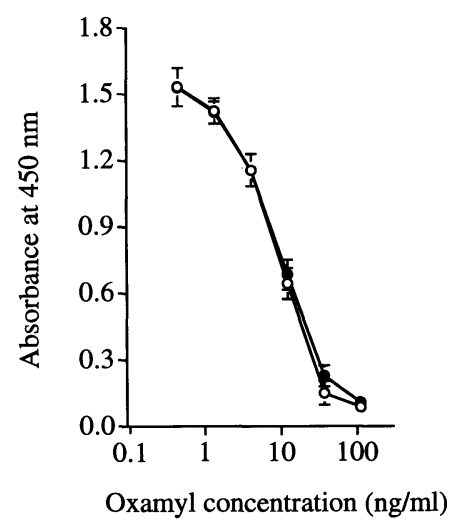

Fig. 4 Effect of methanol extract from potato on heterologous C-ELISA with hapten 6-BSA.

The reactivity of monoclonal antibody OXM 6-8 with oxamyl in the presence $(\bullet)$ and absence $(O)$ of potato extract are shown. Final concentration of methanol in the both was $10 \%$. Each value indicates means \pm SD.

methanol extract from potato was examined on heterologous C-ELISA with hapten 6-BSA.

As shown in Fig. 4, the reactivity curve of oxamyl in the potato extract was almost same as the one without potato extract. The result suggests that heterologous C-ELISA with OXM 6-8 and hapten 6-BSA is useful for determination of oxamyl residues in potatoes.

\section{DISCUSSIONS}

Sensitivity of C-ELISAs for detection of low molecular compounds essentially depends on the design of haptens as immunogens, the reactivity of antibodies toward the objective antigens and also haptens for antigen tracers. For oxamyl, hapten design and preparation of highly reactive antibodies were also important to develop indirect C-ELISA for the sensitive detection.

When haptens for immunizing with mimic structures to target antigens are synthesized, the length of linker should be optimized in order to prepare reactive and sensitive antibodies as much as possible. ${ }^{12)}$ Hapten $\mathbf{3}$ with pentamethylene group between the nitrogen atom in the carbamate moiety and the terminal carboxyl group was shown to be the best for immunogen. This result suggests that the linker of hapten $\mathbf{3}$ has good length for the immune systems in the host animals to recognize oxamyl part of hapten 3 bound on the KLH molecule.

Recent reports have often emphasized that MoAbs have an advantage to determine pesticides on immunoassays. ${ }^{11,13,15-17)}$ The MoAbs with various reactivities were prepared but all of the MoAbs showed more reactivities with oxamyl compared to the PoAbs. This advantage must have been brought from the screening to select highly reactive MoAbs out of PoAb consisting of antibody molecules with various reactivities.

Heterologous C-ELISA with hapten 6-BSA was more sensitive than homologous C-ELISA. This result suggests that the MoAbs bind to hapten 3 stronger than hapten 6 and that hapten 6 enhances the reactivity of the antibodies with oxamyl. The steric hindrance caused by a cyclohexyl ring in the linker is considered to be the major reason for this enhancement, as previously described for bioresmethrin by A. S. Hill et al. ${ }^{14)}$ And, hapten 7 with the cyclohexyl ring attached to the nitrogen atom through one methylene group did not show any enhancement. It is suggested that the addition of this methylene group loses the enhancement. On the other hand, hapten 8 also improved the sensitivity. It is probably caused by $N$-methyl group region, the difference between hapten 3 and hapten 8 .

Even in the existence of methanol, the reactivity of OXM 6-8, the highest reactive MoAb, with oxamyl was kept on heterologous C-ELISA with hapten 6-BSA. This result suggests that this C-ELISA is useful to determine oxamyl residues in samples extracted from crops since its sensitivity is not decreased. And, heterologous C-ELISA with OXM 6-8 and hapten 6-BSA could actually determine oxamyl in the extract from potato to which oxamyl was widely applied. This result showed that the combination of the MoAbs and the haptens, in particular, OXM 6-8 and hapten 6, was the most effective on indirect C-ELISA. The sensitive immunoassay for detection of oxamyl residue in crops has been established by this combination.

\section{ACKNOWLEDGMENTS}

We express special gratitude to Prof. Hideo Ohkawa in Kobe university for his scientific advice and to Mrs. Atsuko Tamori and to Dr. Hideyuki Tanaka in Iatron laboratories Inc. for their informative supports.

\section{REFERENCES}

1) "The Pesticide Manual. A World Compendium. 11th Edition," ed. by C. Tomlin, British Crop Protection Council, Farnham, pp. 909-911, 1997

2) M. Takeda, Y. Ito, Y. Odanaka, K. Komatsu, Y. Maekawa \& O. Matano: "saishin noyaku-no-zanryubunsekiho," Chuo Hoki Publishing, Tokyo, pp. 456-457, 1995 (in Japanese)

3) R. F. Holt \& H. L. Pease: J. Agric. Food Chem. 24, 263 (1976)

4) F. Jung, S. J. Gee, R. O. Harrison, M. H. Goodrow, A. E. Karu, A. L. Braun, Q. X. Li \& B. D. Hammock: Pestic. Sci. 26, 303 (1989)

5) J. H. Skerritt: "NEW FRONTIERS in Agrochemical Immunoassay," ed. by D. A. Kurtz, J. H. Skerritt \& L. Stanker, AOAC INTERNATIONAL, Arlington, pp. 1-16, 1995

6) J. M. Van Emon \& C. L. Gerlach: "Environmental Immunochemical Methods," ed. by J. M. Van Emon, C. L. Gerlach \& J. C. Johnson, ACS Symposium Series 646, American Chemical Society, Washington, DC, pp. 2-8, 1996

7) D. S. Aga \& E. M. Thurman: "Immunochemical Technology for Environmental Applications," ed. by D. S. Aga \& 
E. M. Thurman, ACS Symposium Series 657, American Chemical Society, Washington, DC, pp. 1-20, 1997

8) S. Miyake, A. Hayashi, H. Kita \& H. Ohkawa: Pestic. Sci. 51, 49 (1997)

9) J. F. Kearney, A. Radbruch, B. Liesegang \& K. Rajewsky: J. Immunol. 123, 1548 (1979)

10) K. Ikuta, H. Honma, K. Maotani, S. Ueda, S. Kato \& K. Hirai: Biken J. 25, 171 (1982)

11) A. Abad, J. Primo \& A. Montoya: J. Agric. Food Chem. 45, 1486 (1997)

12) M. H. Goodrow, J. R. Sanborn, D. W. Stoutamire, S. J. Gee \& B. D. Hammock: "Immunoanalysis of Agrochemicals," ed. by J. O. Nelson, A. E. Karu \& R. B. Wong, ACS Symposium Series 586, American Chemical Society, Washington, DC, pp. 119-139, 1995

13) S. Miyake, A. Hayashi, T. Kumeta, K. Kitajima, H. Kita \& H. Ohkawa: Biosci. Biotechnol. Biochem. 62, 1001 (1998)

14) A. S. Hill, D. P. McAdam, S. L. Edward \& J. H. Skerritt: $J$. Agric. Food Chem. 41, 2011 (1993)

15) J. J. Manclus, J. Primo \& A. Montoya: J. Agric. Food Chem. 44, 4052 (1996)

16) S. Miyake, R. Beppu, Y. Yamaguchi, H. Kaneko \& H. Ohkawa: Pestic. Sci. 54, 189 (1998)

17) U. P. D. Zoysa, M. Nakata \& H. Ohkawa: J. Pesticide Sci. 23, 369 (1998)
要 約

殺虫剤オキサミルの免疫化学測定法のためのハプテ ンデザインと抗体調製

三宅司郎，森宗孝介，山口優樹，大出勝也

川田充康，竹脇俊一，湯浅洋二郎

殺虫剂オキサミルを測定するため，間接競合 ELISA 法 が確立された. 4 種類の免疫用ハプテンと 3 種類の分析用 ハプテンを合成し，オキサミルと反応性を示すポリクロー ナル抗体およびモノクローナル抗体を調製した。

免疫用ハプテンの内, $N, N$-dimethyl-2-(5-carboxypentyl)carbamoyloxyirnino-2-(methylthio)acetamide は，オキサミ ルへの抗体を調製するために最も効果的だった。このハプ テンを用いて調製したモノクローナル抗体は，すべてポリ クローナル抗体より高い反応性を示した。なかでもモノク ローナル抗体 OXM6-8 は最も高い反応性を示した。 OXM 6-8 と分析用ハプテン $N, N$-dimethyl-2-(4-carboxycyclohexyl)carbamoyloxyimino-2-(methylthio)acetamide を用いて 間接競合 ELISA 法を構成することにより，最も高い測定 感度が得られた.この系における,オキサミルの 50\%阻害濃 度は $3.6 \mathrm{ng} / \mathrm{ml}$ だった. また, ジャガイモのメタノール抽出 液はこの反応性に影響を与えなかった。 